\title{
Response of Deposit Money Banks to Monetary Policy Dynamics in Nigeria
}

\author{
Ejem, Chukwu Agwu ${ }^{1} \&$ Ogbonna, Udochukwu Godfrey ${ }^{2}$ \\ ${ }^{1}$ Senior Lecturer, Department of Banking and Finance, Abia State University, Uturu, Nigeria \\ ${ }^{2}$ Senior Lecturer, Department of Management Science, Rhema University, Aba, Nigeria \\ Correspondence: Ejem, Chukwu Agwu, Ph.D, Department of Banking and Finance, Abia State University, Uturu, \\ Nigeria.
}

Received: April 7, 2020

doi:10.11114/aef.v7i4.4847
Accepted: April 22, $2020 \quad$ Available online: May 8, 2020

URL: https://doi.org/10.11114/aef.v7i4.4847

\begin{abstract}
This study examined how banks react to the monetary policies transmission mechanisms of the central bank of Nigeria. The data employed were collected from Nigerian Deposit Insurance Cooperation and Central Bank of Nigeria and subjected to various finametric techniques. The major findings are that cash reserve ratio negatively and significantly affects the performance of deposit money banks in Nigeria, while other monetary policy variables exert insignificantly to the performance of deposit money banks. It was also found that apart from banks own shock; banks respond negatively to shocks from major monetary policy instruments. It was observed that Monetary Policy Rate causes bank performance in both in the short run and long run. While, Cash Reserve Ratio, Liquidity Ratio and Saving Deposit Rate do not cause bank performance in the short run but in the long run. It was also found that monetary policy instruments jointly cause bank performance in the short and long run as opposed by individual instruments in Nigeria. The researchers therefore suggest among others that central bank of Nigeria reduce the cash reserve ratio to enable deposit money banks extend more loans to their potential customers, thereby enhance performance.
\end{abstract}

Keywords: return on assets, monetary policy, GMM, VAR, Nigeria

\section{Introduction}

Bank constitutes the engine of growth and development in the economy. It can be likened as the 'Alpha and Omega' of the economy due to its intermediary role between the surplus units (those units of the economy where the disposable income exceeds the expenditure) and the deficit units (those units of the economy where the expenditure exceeds the disposable income at a given period of time). Banks possess the major instruments of monetary policy in the economy. It should, therefore, be handled with care to avert total collapse of the economy. In addition, in the words of Lindgren, Garcia and Saal (1996), the banking system is the primary conduit for transmitting monetary signals. Effective implementation of monetary policy requires that the banking system be able to expand and contract its aggregate financial position in response to policy initiatives without adversely affecting the efficiency of intermediation or depositor confidence. No matter what the specific objectives of monetary policy, an unsound banking system affects the instruments and results of monetary policy as well as the authorities' ability to formulate and conduct monetary policy. This is true regardless of whether quantitative monetary policy formulation focuses on the banking system as a whole or only on the central bank, since the effects on the macro economy of changes in the central banks' financial position are mediated through the banking system.

Banking dates back to the Old Testament biblical era. Egyptians were noted for stockpiling bags of grains in wait for famine and rainy seasons, and such as Israel and the Mediterranean nations. As also seen in the medieval era; the activities of the goldsmiths, and silversmiths in their safe keepings of gold and silver from the merchants of Athens in Greece, and lending of gold to borrowers with higher interest as well as compensating the depositors (merchants of the medieval) with lower interests, thereby making profits. In that process, they are playing two remarkable roles; bridging the gap between the depositors (surplus units) and the borrowers (deficit units); credit creation from the interest given to the depositors for making use of their deposits thereby creating additional credits. These are unique features of modern commercial banking. The importance of banks can also be seen in the settlement and remittance of funds in international trade which ordinarily cannot take place in a vacuum (Ejem, Ogbulu, Ogbonna, Oriko and Jombo, 2020). 
The banking industry occupies a very sensitive space in every economy. This is because of it intermediary role saddled in between the surplus units and the deficit units of the economy (Ekpung, Udude and Uwalaka, 2015). This is seen as a flow mechanism that facilitates the movement of fund across every economic unit in the economy, thereby enhancing the growth and development of any nation. Banks, because of its already mentioned intermediary role and maturity transformation; borrowing short and lending long, are exposed to market failures emanating from asymmetries of information. From the asset perspective, banks take on the risk of valuing project and funding borrowers whose ability to repay is uncertain, whereas the liability dimension is concerned with the confidence of creditors and depositors who have imperfect information on the banks' actual position is essential to a bank's ability to provide deposit and payments service. High leverage and the illiquidity in transparency of bank assets render banks particularly vulnerable to losses of creditor confidence (Nwankwo, 1991). It is worthy to note that the deposit money banks dominated the banking business in Nigeria.

In order to forestall the occurrences of the above trepidations and instill trust and confidence (the chief cornerstone of banking business), the central bank or monetary authority of nation, regularly formulates and transmits monetary policy measures to prevent the foreseeable mayhem in the economy. In the words of Ekezie (2002), one of the principal functions of the Central Bank of Nigeria is to formulate and execute monetary policy to promote stability and sound financial system in Nigeria. For instance in Nigeria, during the Obasanjo regime (2003-2007) where the anal of banking history recorded the most successful monetary policy under the auspices of the central Bank of Nigeria, with the messiah Prof. Chukwuma Charles Soludo, governor of Central Bank of Nigeria in at the helm of affairs in collaboration with Mrs Ngozi Okonjo-Iwela, the Finance Minister. It was when commercial bank capital was recapitalized from two billion naira (N2b) to twenty five billion naira (N25b) which resulted to 24 banks from 89 banks through mergers and acquisition. This period encouraged many Nigerians both in rural and urban areas in inculcating banking habits as banks embarked on aggressive measures to increase their capital base. All of these happened spontaneously, thereby accelerating the rate of economic growth and development, as well as soundness in the banking sector in Nigeria (Ejem etal, 2020).Still on the strategic role of the banking sector, Akomolofe, Danladi, Babalola and Abah (2015) opine that the role of banking sector in the economic development of a nation cannot be overstressed. It is the conduit pipe for channeling idle funds to the productive sector, thereby facilitating the utilization of surpluses in the economy to generate employment and promote economic welfare of the citizens. That central bank of Nigeria is exclusively saddled with the responsibility of formulating and transmitting monetary policy with aim of achieving the macroeconomic objectives of the government. In the words of Akomolofeet'al (2015) the items in deposit money banks financial statement position are influenced by the central bank of Nigeria through the use of direct monetary policies. However, according toNdugbu and Okere (2015), monetary policy remains a critical tool in stimulating the growth and stability of financial institution in most developing economics. In Nigeria, the objectives of these monetary policies are promoting monetary stability, strengthening the external sector performance and generating a sound financial system that will support increased output and employment (Onoh, 2007).

On the relationship between monetary policy and bank performance, Okoye and Eze (2013) found monetary policy measures to have over the years positively influenced performance of the deposit money banks in Nigeria. Despite the counteracting measures, volatility or fluctuations inherent in the monetary policy formulation and transmission (monetary policy dynamics) has undoubtedly affected the performance of deposit money banks in Nigeria. In view of Dare and Okeya (2017), the monetary authorities in Nigeria formulate guidelines and policy variable designed to ensure optimal performance of the banking industry. The performance index of deposit money banks can be viewed from the perspective of profitability and risk. This is because an optimal profits and adequate risk mitigation will go a long to preserve capital of the deposit money banks, thereby assuring its survival, growth and future success. This can only be achieved through the eagle eyes of the central banks or regulatory authorities. This because banking sector is perceived to be a veritable medium transmitting the monetary policy. Again, monetary policies from all explanations have a direct link with the bank performance.(Rose and Hudgins, 2010; Nguyen, Vu and Le (2017).

Explicitly, deposit money banks do not operate in a vacuum. They do so within the ambit of monetary policy framework, also discretionary policies of banks and under the auspices of regulatory bodies empowered within the economy. The central bank of Nigeria, from inception has employed arsenals of regulatory tools at its disposal to regulate and control the cost, volume, availability and direction of money credit in order to influence the broader objectives of the policy which include price stability, high level of employment, sustainable economic growth development and balance of payments. These monetary policy control measures are adjudged to be effective to influencing deposit money banks to satisfying the various constituencies or stakeholders in the banking business such as the depositors, the community and shareholders. Most of the effective tools used by the monetary authority to achieving their macroeconomic objectives are liquidity ratio (LR), monetary policy rate (MPR), open market operation (OMO), required reserve ratio (RRR), bank rate (BR), selective credit control (SCC) and moral suasion (MS) (Onoh, 2007; Udude, 2014; Ekpunget'al, 2015; Dare and Okeya, 2017).

In Nigeria, despite the pervasive and regular interventions by the monetary authorities through various monetary policy 
measures, banks especially deposit money banks are still recording pockets of non performances in the discharge of their duties. These can be traced through cases of loan delinquencies, liquidity crisis, poor services etc, and hence making banks to be vulnerable. According to Lindgren, Garcia and Saal (1996), the vulnerability of banks leads to public policy concern because of negative externalities related to bank failures. These negative externalities occur when bank failures spill over to others banks and economic agents. Contagious runs and attendant domino effects and payments system disruption are the main negative externalities associated with bank fragility. Again, runs to quality due to non performance of banks that is, from unsound banks to safer havens, may be rational but can disrupt the financial system. However due the above concerns, the researchers delved into knowing the performance of deposit money banks and monetary policy relations in Nigeria. The subsequent sections of this study are organized as follows; section two will take care of review of conceptual, theoretical and empirical literature; section three addresses the materials and methods of analysis adopted; section four analyses the data, results and interpretation while section five handles conclusion and recommendations for policy making, finally section six takes care of suggestion for further studies.

\section{Review of Related Literature}

\subsection{Conceptual Literature}

Monetary policy refers to the actions taken by a central to regulate the value of supply and cost of money with view to achieving the overall macroeconomic objectives of the economy. It can also refer to a blend of measures and or set of instruments designed by the central bank to regulate the value, supply and cost of money consistent with the absorptive capacity of the economy or the expected level of economic activity without necessarily generating undue pressure on domestic prices and exchange rate. It can also be seen as the employment of monetary instruments to checkmate or control the volume, cost, availability and the direction of money and credit in an economy to achieve some the macroeconomic objectives (Osiegbu, 2006; Central Bank Nigeria, 2009; Akomolofeet'al, 2015). In words of Onuorah, Shaib, Oyathelemi and Friday (2011),'monetary policy is a deliberate attempt by the monetary authority to control the money supply and credit condition in the economy so as to achieve certain economic objective'. Akanbi and Ajagbe (2012) viewed monetary policy as an instrument given to the central bank of Nigeria (CBN) by the federal government that is, it is a function which is a documentary policy control the aggregate demanded in the circulation or cost. Akanbi and Ajagbe (2012) further stressed that the policy is to see to the stability in wages and prices of goods and services. That it is also necessary to control the volume of in circulation and give the domestic money a value via other controls. Monetary policy according to Dare and Okeya (2017) is referred to any policy increase designed to by the government or the central bank to control the cost, availability and supply of credit. While Ekezie (2002) on it perspective saw monetary policy as combination of measures designed to regulate the value, supply and cost of money in an economy, in consonance with the level of economic activities. While Nzotta (2004) defined monetary policy as'combination of discretionary measures designed to regulate and control the money supply in an economy by the monetary authorities, with a view of achieving stated or desired macroeconomic goals'.

In the words of Onoh (2007), the objectives of monetary and fiscal policies are not different from the general objectives of macroeconomic policy of which monetary and fiscal policies constitute an integral part. Each country's economic objectives might differ slightly because of the peculiar nature of the problems to be solved and the environment in which those problems exist. Objectives which are emphasized in one country may not receive the same attention in another. The main economic objectives or goals of a free market economy are mainly; high level of employment, stable prices, rapid growth of gross national product, and favourable balance of payment. It is pertinent to note that monetary and fiscal policies are important bodies of macroeconomic policy framework. They cannot be separated from the macroeconomic policy frame work. The rest of the objectives are equally important and are also achieved through the application of the relevant instruments of macroeconomic policy. Generally, policy instruments are interdependent. To achieve good results monetary and fiscal policy instruments, together with instruments of direct control, have to be applied simultaneously but in varying degrees and directions. It is important that the instruments work harmoniously. If the intention of monetary policy is to contract money supply, the instrument must be deployed along the line of lowering money supply. For example, open market operations involving the sale of government securities to reduce the quantity of currency in circulation or the level of money supply in order to bring down the rate of inflation should not be countered with deficit fiscal policy, which expands rather than contract money supply.

On performance of deposit money banks, Rose and Hudgins (2010) described performance as 'how adequate a financial firm meets the needs of its stockholders (owners), employees, depositors and other creditors and borrowing customers'. Succinctly, deposit money banks should endeavour to adhere strictly the postulations qua regulatory authorities, at least to be at peace with their operating policies, loans and investment. These will in a long earn the trust and confidence of the public they serve. Rose and Hudgins (2010) further unearth that success and lack of success of these institutions in meeting the expectations of others is usually revealed by a careful study of their financial statement. In this context, profitability and risk are the major standpoints of performance which is natural and inheres deposit money banks. An 
adequate profits and a good risk mitigation measure capital, assures growth and survival of a financial institutions and other businesses In measuring the performance of banks and other financial institution, the return on asset (ROA) is commonly used.

Return on Assets or the ability of management to generate income from assets is represented below;

$$
\mathrm{ROA}=\frac{\text { Net Income }}{\text { Total Assets }}
$$

(Rose and Hudgins, 2010)

\subsubsection{Monetary Policy Instruments for Controlling the Banks' Monetary Base in Nigeria}

There are a number of monetary policy instruments in the arsenals of the authorities designed to achieve specific or general policy objectives. Four of these instruments are suitable for controlling the monetary base as well as enhancing the performance of the deposit money bank. They are: Minimum reserve requirement (MRR); Special deposit (SD); Open market operation (OMO); and Monetary policy rate (MPR). Policy instruments MRR and SD can influence the level of the deposit money banks with the Central Bank of Nigeria (CBN). Instruments; OMO and MPR impact on the currency (C) component of the monetary base. These set of instruments can be activated to contract or expand the monetary base depending on the state of the economy and the policy stance of government. In modern economies where inflation is the bane of the economy the policy stance will be to reduce monetary base. By raising the MRR of the banking system the excess or the free reserve, the platform upon which the deposit money banks depend for the multiple credit expansion is reduced as well as the bank credit multiplier or coefficient. The imposition of SD or the stabilization securities as was the case in Nigeria between the 1970s and 1990s also exert similar influence on the deposit money banks' free or excess reserves (Onoh, 2007). The instrument of MRR is regarded as by many as authorities as the instrument of last resort and is rarely used either because of custom or convention or because the law has fixed the MRR and the corresponding percentages called the reserve ratio ( the percentage of cash to current liabilities and the percentage of cash to deposit liabilities). The sum of the two constitutes the MRR which each bank must keep with the central bank as its statutory minimum reserve requirement. The sizes of the current liabilities and the deposit liabilities of each deposit money bank will determine the amount of cash each bank will keep at all times with the central bank as its statutory minimum reserves. The MRR which will guarantee a stable operation of the banking system and monetary equilibrium is difficult to determine or predict. Once it is fixed monetary authorities consider it safer to navigate monetary policies in such a manner that the ratios are kept stable over a long period. Because of the difficulty of predicting the right minimum reserves, it is considered not only risky but dangerous to toy with the instrument in the attempt to influence the reserve component of the monetary base equation, the monetary base itself being an unstable indicator variable under constant onslaught from exogenous variables (Onoh, 2007). Because of the inherent risk of the adjustment of MRR, instruments OMO and MPR especially $\mathrm{OMO}$, has become popular and the most potent instrument for influencing the monetary base. It influences the currency component of the monetary base. With the reserve of the monetary base equation kept constant the currency component is influenced by CBN engaging in OMOs by selling government and other accredited foreign currencies or securities and other primary assets in the portfolio of the CBN. The sale of securities to the public reduces the volume of currency in circulation and the level of money supply. Prices fall gradually with the reduction in the volume of currency in circulation (Onoh, 2007). Another vehicle for influencing the volume of currency in circulation is the instrument of MPR. By increasing the MPR, CBN discourages borrowing by the deposit money banks for lending to the public. Lending to the public by deposit money banks help to swell the currency in circulation. If the policy stance is that of monetary contraction CBN sells securities to the non bank public and raises the MPR and thereby reduces the currency in circulation, the other components of the monetary base. If the policy stance should be that of monetary expansion the process is reversed, CBN repurchases securities from the non bank public and lowers the MPR to encourage more lending by deposit money banks (Onoh, 2007).

\subsection{Theoretical Literature}

Here the researchers examined theories that support the influence of monetary policies on the direction of economic activities and excerpts of banking theories to rely on for satisfaction of banks' stakeholders.

\section{The Keynesian Theory}

Keynesian Economists see the monetary policy efficacy basically lies on interest rate. In Keynesian monetary theory assertions, an increase or decrease in money supply is caused by open market purchase or sale of government debt instrument by the central bank of any nation. Excess demand for government securities, mostly when government is also involved in the repurchase of such securities, pushes up the prices of those securities, as well raises the capital gain and reduces the annual interest yield of those securities. The moment government resorts to enter the market it normally buys 
or sells securities on large scale. If the aim is to stimulate a sluggish economy, government repurchases securities on a large scale and injects cash into the economy to increase aggregate demand for goods and services, and encourage more output. If the intention is to lower the high inflationary rate and create aafavourable environment for business mostly financial institution to thrive, government sells securities on a large scale. A large volume of money is withdrawn from circulation and the level of money supply falls, dragging transactions balances of the community to a lower level. As a result, general prices fall bringing down the rate of inflation (Onoh, 2007; Ekpung, Udude and Uwalaka, 2015)

\section{The Classical Monetary Theory}

The classical theory was expanded by the Quantity theory of money suppliers by say's law, Walras' law and others. In elucidating the Quantity Theory of Money, Fisher used equation to explain a cause and effect in relationship between the quantity of money and the general price level.

Stating, $\quad$ MV = PT; where $\mathrm{M}=$ Quantity (Stock) of money supplied V = Velocity of money in circulation $\mathrm{P}=$ Price levels $\mathrm{T}=$ Volume of transactions

Or M V = PQ; where ' $Q$ ' is replaced with ' $T$ ' meaning Quantity of goods involved.

The above equation states that the level of prices in any economy is directly proportional to the quantity of money in circulation such that a given percentage changes in the stock of money will exert an equal percentage change in the price level, normally in the same direction. In addition, Sir Fisher assumed that for every transaction, there is both a buyer and a seller and that sale equates receipts. Fisher further opined that sale is the product of the number of transactions and average number of times it changes hands over the same period of time(Dare and Okeya 2017; Ejem et al, 2020)

\section{The Monetarist Theory}

The monetarist school of thought argued that that money is demanded as a set of wealth of an economic agent. They see money as any other commodity. Friedman's argument to monetary theory is commendable because it does not dissipate energy trying to explain the motives for holding money; instead he analyzed the factors that determine how much money people will want to hold under various circumstances. Succinctly the fundamental difference between the Keynesian and Monetarists lies in the notion of money being a close substitute for financial assets, while the Keynesian are of the opinion that that money is a close substitute for financial assets because of its liquid form, the monetarists argue that money is not a particular close substitute for any specific range of assets. However, based on their belief, the Keynesians would expect that there was a close relationship between the demand for money and the yield (that is rate of interest) on money substitutes. On the other hand, the monetarists would expect no significant relationship because of their belief that money is a substitute for all assets alike (Udude, 2014; Ekpunget'al, 2015; Ejem et al, 2020).

\section{Anticipated Income Theory}

This theory reveals that the earning power and reputation of the borrower is the ultimate guarantee to meeting up with the short term obligation and liquidity of bank depends on the anticipated income of the borrower, not really the use of fund. This theory tenaciously cling to the movement toward self amortizing commitments by banks and emphasize that systematic repayment schedule on many types of loans and serial maturity debts, has the ability to provide an automatic liquidity schedule out the repayment capabilities of the borrower (Nwankwo, 1991; Ekpunget'al, 2015). Nwankwo (1991) further stressed that 'the resulting cash flow thus becomes an important source of cash flow for the lender. That liquidity in credit granting may diminish in periods of cyclical expansion, restoration will ocurr during periods of contraction when loan growth slows while repayment continues.

\subsection{Empirical Literature}

Researchers around the world and mostly Nigerian scholars have done greatly to unravel the relationship and impact of monetary policy and banks' performance. For instance, Ajayi and Atanda (2012) employed Enger-Granger two-step cointegration to examine the impact of monetary policy on the performance of banks in Nigeria. The empirical results revealed that monetary policy instruments are ineffective to trigger credit in the long run but found that bank rate, inflation rate and exchange rate have positive relationship with bank credit, while negative relationship exist between liquidity ratio, cash reserve ratio and total credit of the banks.

Applying with regression model, Akanbi and Ajagbe (2012) analyzed the impact of monetary policy on commercial banks in Nigeria. It was found that net profit, liquidity ratio, cash ratio and interest rate on savings insignificantly relate to the performance of commercial banks in Nigeria.

Akomolofeet'al(2015) employed variants of panel data analysis (pool regression, fixed effect and random effect) to test the model. made empirical investigation to know the impact of monetary policy on commercial banks' performance in Nigeria. After the analysis, it favoured fixed effect regression using Hausman test. The results revealed that banks performance have positive relationship with monetary policy in Nigeria. The finding affirms the efficacy of monetary policy measures in regulating the banking sector in order to enhance performance. The researchers went ahead in 
conformity with the result to recommend that interest rate policy should be examined properly by the central bank of Nigeria in such a manner that friendly loan advancement in the country could be enhanced.

With Pearson Product moment correlation technique,Ude (2015) examined the impact of monetary policy instruments on profitability of commercial banks in Nigeria using the Zenith Bank Plc experience. After a thorough empirical analysis, the study discovered that cash reserve ratio, liquidity ratio and interest rate did not have significant impact on the profit before tax. Also minimum rediscount rate was found to have significant effect on the profit before tax of the bank.

Employing Ordinary Least Square.Ndugbu and Okere (2015), examined the impact of monetary policy on the performance of deposit money banks - the Nigerian Experience, Ordinary Least Square found that amongst all the monetary policy variables (bank deposit rate, bank lending rate, cash reserve ratio and liquidity ration) considered in the model, only bank deposit rate has significant relationship though inverse relationship.

In Vietnam focusing 20 commercial banks which were doing business in Vietnam's banking market, between 2007 to 2014, Nguyen, Vu and Le (2017) looked at the impact of monetary policy on commercial banks' profit employing panel data regression. The results showed that there is a positive relationship between banks' profits and monetary policies. It was found that Monetary Base positively and significantly impact on bank's profit.

Dare and Okeya (2017) applied multiple linear regression technique to investigated the impact of monetary policy on the performance of commercial banks in Nigeria. The study focused on United Bank of Africa (UBA) from 2009 to 2014 inclusive and found MPR, CRR and LR to insignificantly relate to ROA. The study shows that the monetary policy initiatives of the central bank of Nigeria are not properly targeted to influencing banks' performance in Nigeria.

\section{Methodology}

\subsection{Data}

The data used are made up 30 observations from 1990 to 2018 standing for the variables; Return on Assets (ROA)(proxy of bank performance) and monetary policy (Monetary Policy Rates (MPR), Saving Deposit Rate (SDR), Cash Reserve Rates (CRR) And Liquidity Ratio (LDR)) collected from Nigerian Deposit Insurance Cooperation (NDIC) and Central Bank of Nigeria (CBN).

The time series plot of the data is shown in figure I below,

ROA

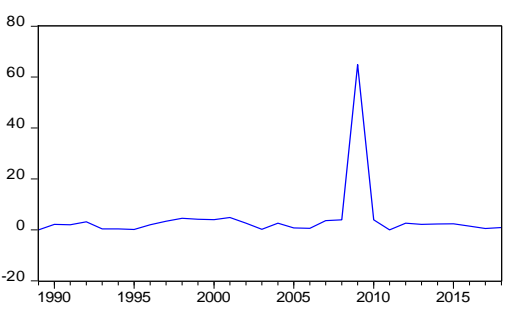

CRR

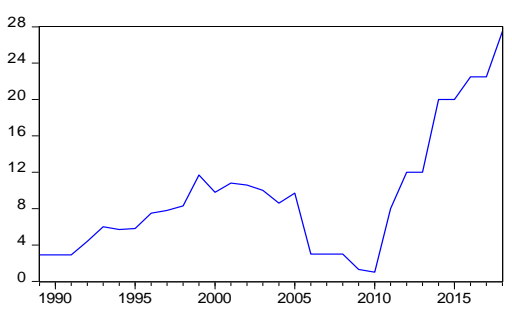

SDR

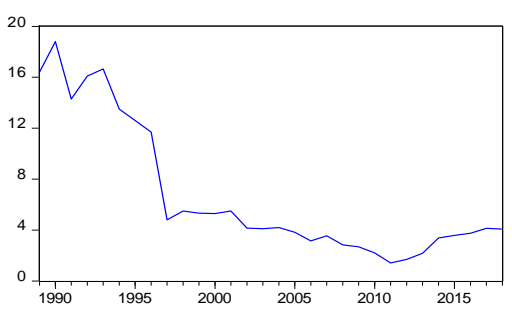

MPR

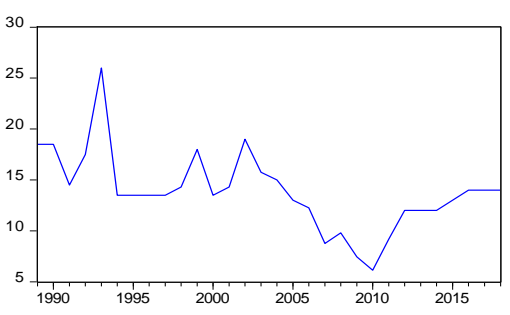

LDR

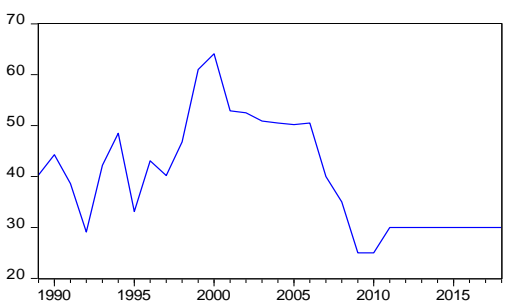

Figure 1. The time series of ROA, MPR, CRR, LDR and SDR 


\section{Authors' computation output using E-view 10}

From the figure 1 above, it shows that all trended upward and downward, sometimes undulation and plateau over the period of the study, indicating non-stationarity of the variables as expected. Accept ROA that recorded a sharp trend upward from 2008 to 2010, which is not violent fluctuation. In all the variables there are periods of troughs and peaks. It can be recognize as outliers in the years.

\subsection{Methods}

In testing the stationarity of the variables, the Augmented Dickey Fuller (ADF) unit root test is engaged; also to examine if long run relationship exists between the dependent and independent variables in this paper, Johansen Cointegration is used. In testing for multicollinearity, the correlation matrix is used in this study. Because of the dynamic nature of the variables both Vector Autoregressive (VAR) and Generalized Method of Moments (GMM) were employed to testing the models.

\subsection{Model Specification}

Starting from the Functional form;

$$
\text { Return on Assets = f (Monetary Policy Variables) }
$$

Return on Assets = f (Monetary Policy Rates, Cash Reserve Rates, Liquidity Ratio,

$$
\text { Saving Deposit Rate) }
$$

$$
\mathrm{ROA}=\mathrm{f}(\mathrm{MPR}, \mathrm{CRR}, \mathrm{LDR}, \mathrm{SDR})
$$

Then, the explicit form;

The reduced VAR model, incorporating Return on Assets (ROA), Monetary Policy Rates (MPR), Saving Deposit Rate (SDR), Cash Reserve Rates (CRR) and Liquidity Ratio (LDR) is stated as below

$$
\begin{aligned}
& \operatorname{ROA}_{\mathrm{t}}=\alpha_{01}+\alpha_{11} \mathrm{ROA}_{\mathrm{t}-1}+\alpha_{21} \mathrm{MPR}_{\mathrm{t}-1}+\alpha_{31} \mathrm{CRR}_{\mathrm{t}-1}+\alpha_{41} \mathrm{LDR}_{\mathrm{t}-1}+\alpha_{51} \mathrm{SDR}_{\mathrm{t}-1}+\mathrm{U}_{\mathrm{t} 1} \\
& \mathrm{MPR}_{\mathrm{t}}=\beta_{02}+\beta_{12} \mathrm{ROA}_{\mathrm{t}-1}+\beta_{22} \mathrm{MPR}_{\mathrm{t}-1}+\beta_{32} \mathrm{CRR}_{\mathrm{t}-1}+\beta_{42} \mathrm{LDR}_{\mathrm{t}-1}++\beta_{52} \mathrm{SDR}_{\mathrm{t}-1}+\mathrm{U}_{\mathrm{t} 2} \\
& \mathrm{CRR}_{\mathrm{t}}=\Upsilon_{03}+\Upsilon_{13} \mathrm{ROA}_{\mathrm{t}-1}+\Upsilon_{23} \mathrm{MPR}_{\mathrm{t}-1}+\Upsilon_{33} \mathrm{CRR}_{\mathrm{t}-1}+\Upsilon_{43} \mathrm{LDR}_{\mathrm{t}-1}+\Upsilon_{53} \mathrm{SDR}_{\mathrm{t}-1}+\mathrm{U}_{\mathrm{t} 3} \\
& \mathrm{LDR}_{\mathrm{t}}=\mathrm{Z}_{04}+\mathrm{Z}_{14} \mathrm{ROA}_{\mathrm{t}-1}+\mathrm{Z}_{24} \mathrm{MPR}_{\mathrm{t}-1}+\mathrm{Z}_{34} \mathrm{CRR}_{\mathrm{t}-1}+\mathrm{Z}_{44} \mathrm{LDR}_{\mathrm{t}-1}++\mathrm{Z}_{54} \mathrm{SDR}_{\mathrm{t}-1}+\mathrm{U}_{\mathrm{t} 4} \\
& \quad \mathrm{SDR}_{\mathrm{t}}=\partial_{05}+\partial_{15} \mathrm{ROA}_{\mathrm{t}-1}+\partial_{25} \mathrm{MPR}_{\mathrm{t}-1}+\partial_{35} \mathrm{CRR}_{\mathrm{t}-1}+\partial_{45} \mathrm{LDR}_{\mathrm{t}-1}+\partial_{55} \mathrm{SDR}_{\mathrm{t}-1}+\mathrm{U}_{\mathrm{t} 5}(8)
\end{aligned}
$$

While the GMM explicit form in first difference is;

$$
\mathrm{ROA}=\mathrm{b}_{0}+\mathrm{b}_{1} \mathrm{ROA}_{\mathrm{t}-1}+\mathrm{b}_{2} \mathrm{MPR}_{+} \mathrm{b}_{3} \mathrm{MPR}_{\mathrm{t}-1} \mathrm{~b}_{4} \mathrm{CRR}+\mathrm{b}_{5} \mathrm{CRR}_{\mathrm{t}-1}+\mathrm{b}_{6} \mathrm{LDR}+\mathrm{b}_{7} \mathrm{LDR}_{\mathrm{t}-1}+\mathrm{b}_{8} \mathrm{SDR}+\mathrm{b}_{9} \mathrm{SDR}_{\mathrm{t}-1}+\mathrm{e}_{\mathrm{t}-1}
$$

Where $\mathrm{U}_{\mathrm{t}}$ are white noises that capture the innovations or shocks to the VAR system.

\section{And final, the Operational form (Apriori Expectation);}

$\boldsymbol{\alpha}_{1}, \boldsymbol{\alpha}_{2}, \boldsymbol{\alpha}_{3} \boldsymbol{a n d} \boldsymbol{\alpha}_{4}>\mathbf{0}<\mathbf{0}$, are coefficient of MPR, CRR, LDR, SDR. It is expected that monetary policy variables will either positively or negatively influence deposit money banks' performance, in affirmation of the monetary policy dynamism..

\section{Analysis and Discussion}

The researchers commenced the analysis with data description as shown below;

\subsection{Descriptive Statistics}

Table 1. Descriptive Statistics ROA, MPR, CRR, LDR and SDR

\begin{tabular}{|l|c|c|c|c|c|}
\hline & ROA & MPR & CRR & LDR & SDR \\
\hline Mean & 4.207000 & 13.88133 & 9.373333 & 40.12667 & 6.711333 \\
\hline Median & 2.225000 & 13.50000 & 8.150000 & 40.10000 & 4.140000 \\
\hline Maximum & 64.92000 & 26.00000 & 27.50000 & 64.10000 & 18.80000 \\
\hline Minimum & -0.040000 & 6.130000 & 1.000000 & 25.00000 & 1.410000 \\
\hline Std. Dev. & 11.56369 & 3.865720 & 6.891621 & 10.79955 & 5.318112 \\
\hline Skewness & 5.060927 & 0.711373 & 1.067086 & 0.425798 & 1.092443 \\
\hline Kurtosis & 27.11088 & 4.866871 & 3.375811 & 2.179709 & 2.613412 \\
\hline Jarque-Bera & 854.7330 & 6.886764 & 5.869901 & 1.747618 & 6.153972 \\
\hline Probability & 0.000000 & 0.031956 & 0.053133 & 0.417359 & 0.046098 \\
\hline Sum & 126.2100 & 416.4400 & 281.2000 & 1203.800 & 201.3400 \\
\hline Sum Sq. Dev. & 3877.851 & 433.3699 & 1377.339 & 3382.279 & 820.1871 \\
\hline Observations & 30 & 30 & 30 & 30 & 30 \\
\hline
\end{tabular}




\section{Authors' computation output using E-view 10}

Table 1 shows summary of statistics that describe the distributional features of all the data. The variables recorded average of the following; 4.20\%, $13.88 \%, 9.37 \%, 40.12$ and $6.71 \%$ for ROA, MPR, CRR, LDR and SDR respectively. The risk (standard deviation) inherent in each of the monetary policy variables are 3.86, 6.89, 10.79 and 5.31 for MPR, CRR, LDR and SDR respectively. MPR, CRR and LDR showed Kurtosis greater than 3, indicating a leptokurtic distribution, while LDR and SDR are lower than 3 showing platykurtic distributions. Judging with skewness none is mesokurtic or symmetric or normal distribution. The skewness coefficients are 5.060927, 0.711373, 1.067086, 0.425798 and1.092443 for ROA, MPR, CRR, LDR and SDR respectively, meaning all have positive stewed distribution. JarqueBera normality distribution test statistic has $0.000000,0.031956$ and 0.046098 probability for ROA, MPR and SDR variables respectively, suggesting evidence of abnormal distribution while CRR and LDR have 0.053133and 0.417359 which a clear evidence of normal distribution at $5 \%$.

\subsection{Global Utility Test}

In the macroeconomic analysis, it is pertinent to check the global utility or usefulness of the specified models. To achieve this, the researchers engaged correlation matrix and ordinary least square.

\subsection{Multicollinearity Test}

Table 2.Correlation Matrix

\begin{tabular}{|c|c|c|c|c|c|}
\hline & ROA & MPR & CRR & LDR & SDR \\
\hline ROA & 1.000000 & -0.338130 & -0.235694 & -0.236618 & -0.174815 \\
\hline MPR & -0.338130 & 1.000000 & 0.072084 & 0.415718 & 0.635569 \\
\hline CRR & -0.235694 & 0.072084 & 1.000000 & -0.177207 & -0.376283 \\
\hline LDR & -0.236618 & 0.415718 & -0.177207 & 1.000000 & 0.118386 \\
\hline SDR & -0.174815 & 0.635569 & -0.376283 & 0.118386 & 1.000000 \\
\hline
\end{tabular}

\section{Authors' computation output using E-view 10}

Table 2 reveals the correlation of the variables. The correlations between ROA, MPR, CRR, LDR and SDR range from -0.177207 to 0.635569 showing that the variables are not linearly correlated. Therefore, the researchers have enough evidence to adduce no presence of multicollinearity in the model.

Table 3. Ordinary Least Square (OLS) Methods

\begin{tabular}{|c|c|c|c|c|}
\hline $\begin{array}{l}\text { Dependent } \\
\text { ROA }\end{array}$ & & & & \\
\hline $\begin{array}{r}\text { Variable } \\
\end{array}$ & Coefficient & Std. Error & t-Statistic & Prob. \\
\hline MPR & -0.110413 & 0.931185 & -0.118573 & 0.9066 \\
\hline CRR & -0.633491 & 0.394087 & -1.607490 & 0.1205 \\
\hline LDR & -0.275230 & 0.235805 & -1.167193 & 0.2541 \\
\hline SDR & -0.571841 & 0.656636 & -0.870865 & 0.3921 \\
\hline $\mathrm{C}$ & 26.55950 & 9.834961 & 2.700519 & 0.0122 \\
\hline R-squared & 0.208261 & & & \\
\hline Adjusted R-squared & 0.081582 & & & \\
\hline F-statistic & 1.644013 & & & \\
\hline Prob(F-statistic) & 0.194524 & & & \\
\hline Durbin-Watson stat & 2.386895 & & & \\
\hline
\end{tabular}

\section{Authors' computation output using E-view 10}

Table 3 depicts the Ordinary Least Square (OLS) estimated model for the relationship between monetary policy and performance of deposit money banks. From the table Durbin-Watson statistics is 2.386895, showing no presence of autocorrelation. But F-statistic value is 1.644013 with p-value of 0.194524 suggesting the null hypothesis cannot be rejected, there is overall insignificance and invalid for comparison. Therefore cannot be used for further analysis and policy formulation.

\subsection{Stationarity/Unit Root Test}

This is statistical valid procedure in macroeconomics time series analysis that assists to determining the best estimation method for the data. It is due to the peculiarities of time series data. To do this the popular Augmented Dickey Fuller (ADF) unit root/stationary test is used as shown below. 
Table 4. Augmented Dickey Fuller Unit Root Test

\begin{tabular}{|c|c|c|c|c|c|c|c|c|}
\hline \multirow[t]{3}{*}{ Variables } & \multirow[t]{3}{*}{$\begin{array}{l}\text { Lag } \\
\text { Length }\end{array}$} & \multicolumn{3}{|l|}{ LEVEL } & \multicolumn{3}{|c|}{$1^{\text {st }}$ DIFFERENCE } & \multirow[t]{3}{*}{ Remarks } \\
\hline & & \multirow{2}{*}{ ADF Stat/Prob. } & \multicolumn{2}{|c|}{ Critical Values } & \multirow[t]{2}{*}{ ADF Stat/Prob. } & \multicolumn{2}{|c|}{ Critical Values } & \\
\hline & & & $5 \%$ & $10 \%$ & & $5 \%$ & $10 \%$ & \\
\hline LnROA & 0 & $-3.24891(0.0284)$ & -2.981038 & -2.629906 & $-6.673502(0.0000)$ & -2.99878 & -2.635542 & @ 1(1) \\
\hline LnMPR & 0 & $-2.380669(0.1556)$ & -2.967767 & -2.622989 & $-6.183067(0.0000)$ & -2.971853 & -2.625121 & @ 1(1) \\
\hline LnCRR & 0 & $-1.460578(0.5389)$ & -2.967767 & -2.622989 & $-4.908116(0.0005)$ & -2.971853 & -2.625121 & @ 1(1) \\
\hline LnLDR & 0 & $-1.612760(0.4635)$ & -2.967767 & -2.622989 & $-748665(0.0001)$ & -2.971853 & -2.625121 & @ 1(1) \\
\hline LnSDR & 0 & $-1.617815(0.4610)$ & -2.967767 & -2.622989 & $-5.206266(0.0002)$ & -2.971853 & -2.625121 & @1(1) \\
\hline
\end{tabular}

\section{Authors' computation output using E-view 10}

Table 4 shows the stationary test for both level and first difference data. The results indicates that the level data are all non stationary while the all the variables; ROA, MPR, CRR, LDR and SDR are stationary or integrated at order one. It can also be seen that ADF Statistic of all the variables are more negative than their critical values of 5\% and $10 \%$ at first difference.

\subsection{CointegrationandLong run Relationship Test}

This is necessary to know if there exist equilibrium relationships between the variables; ROA, MPR, CRR, LDR and SDR as shown below;

Table 5. Johansen Cointegration Test

\begin{tabular}{|c|c|c|c|c|}
\hline \multicolumn{6}{|l|}{ Unrestricted Cointegration Rank Test (Trace) } \\
\hline Hypothesized & & Trace & 0.05 & \\
\hline No. of CE(s) & Eigenvalue & Statistic & Critical Value & Prob.** \\
\hline None $*$ & 0.807562 & 77.68889 & 69.81889 & 0.0103 \\
\hline At most 1 & 0.631568 & 38.13730 & 47.85613 & 0.2960 \\
\hline At most 2 & 0.399414 & 14.17330 & 29.79707 & 0.8308 \\
\hline At most 3 & 0.076246 & 1.936910 & 15.49471 & 0.9958 \\
\hline At most 4 & 0.001394 & 0.033485 & 3.841466 & 0.8548 \\
\hline
\end{tabular}

\begin{tabular}{|c|c|c|c|c|}
\hline \multicolumn{6}{|l|}{ Unrestricted Cointegration Rank Test (Maximum Eigenvalue) } \\
\hline Hypothesized & & Max-Eigen & 0.05 & \\
\hline No. of CE(s) & Eigenvalue & Statistic & Critical Value & Prob.** \\
\hline None $*$ & 0.807562 & 39.55159 & 33.87687 & 0.0095 \\
\hline At most 1 & 0.631568 & 23.96400 & 27.58434 & 0.1360 \\
\hline At most 2 & 0.399414 & 12.23639 & 21.13162 & 0.5245 \\
\hline At most 3 & 0.076246 & 1.903425 & 14.26460 & 0.9927 \\
\hline At most 4 & 0.001394 & 0.033485 & 3.841466 & 0.8548 \\
\hline
\end{tabular}

\section{Authors' computation output using E-view 10}

Table 5 indicates that unrestricted rank tests (Trace and Maximum Eigenvalue) have trace statistics 77.68889 and Max-Eigen of 39.55159 with p-values of 0.0103 and 0.0095 respectively at 'None' hypotheses. That shows one cointegration equation at 5\% level of significance among the variables. This shows that long run relationship exists between the dependent variable bank performance proxied by ROA and independent variables; monetary policy (MPR, CRR, LDR and SDR).

\subsection{Causal Relationship between ROA, MPR, CRR, LDR and SDR}

In macroeconomic analysis, causality test is common tool used in to check if causality exists or otherwise, between any two variables;

Table 6. Pairwise Granger Causality Test Results

\begin{tabular}{|l|c|r|r|}
\hline Null Hypothesis: & Obs & F-Statistic & Prob. \\
\hline LNMPR does not Granger Cause LNROA & 24 & 4.62103 & 0.0232 \\
\hline LNROA does not Granger Cause LNMPR & 24 & 0.35466 & 0.7060 \\
\hline LNCRR does not Granger Cause LNROA & & 0.58865 & 0.5649 \\
\hline LNROA does not Granger Cause LNCRR & 24 & 0.34837 & 0.5637 \\
\hline LNLDR does not Granger Cause LNROA & 24 & 0.22179 & 0.7103 \\
\hline LNROA does not Granger Cause LNLDR & & 3.782940 & 0.8031 \\
\hline LNSDR does not Granger Cause LNROA & & 0.0414 \\
\hline LNROA does not Granger Cause LNSDR
\end{tabular}




\section{Authors' computation output using E-view 10}

From the table 6 above, MPR granger cause ROA as such causally prior to ROA (F-stat ${ }_{\mathrm{MPR}}=4.63103$; Prob ${ }_{\mathrm{MPR}}=0.0232$, significant at $5 \%$ ). In the other way round, ROA granger cause SDR (F-stat ${ }_{\mathrm{ROA}}=3.78296$; Prob $_{\mathrm{ROA}}=0.0414$, significant at 5\%). That suggests a unidirectional causality between MPR, SDR and ROA. Other variables CRR and LDR have no identifiable causality with MPR since their p-values are greater than the significant levels of $5 \%$ and $10 \%$.

\subsection{Contemporaneous Relationship between ROA, MPR, CRR, LDR and SDR}

This is important in determining the relationship between performance of deposit money banks and monetary policy dynamics. It can be recalled that OLS exhibits unsatisfactory global utility, and was therefore abandoned. Due to the dynamic nature of the variables, the researchers therefore adopt the General Method Moments (GMM).

Table 7. General Methods Moment

\begin{tabular}{|c|r|r|r|r|}
\hline Variable & Coefficient & Std. Error & t-Statistic & Prob. \\
\hline LNMPR & 0.218649 & 0.920174 & 0.237617 & 0.8143 \\
\hline LNCRR & -0.645616 & 0.243791 & -2.648241 & 0.0144 \\
\hline LNLDR & -0.468683 & 0.948601 & -0.494078 & 0.6259 \\
\hline LNSDR & -0.747693 & 0.453883 & -1.647325 & 0.1131 \\
\hline C & 4.241091 & 3.203120 & 1.324050 & 0.1985 \\
\hline R-squared & 0.232518 & Mean dependent var & 0.594099 \\
\hline Adjusted R-squared & 0.099043 & S.D. dependent var & 1.243059 \\
\hline S.E. of regression & 1.179896 & Sum squared resid & 32.01958 \\
\hline Durbin-Watson stat & 1.705439 & J-statistic & 2.903738 \\
\hline Instrument rank & 9 & Prob(J-statistic) & 0.574062 \\
\hline
\end{tabular}

\section{Authors'computation output using E-view 10}

Table 7 reveals the estimation of the model using Generalized Method of Moments (GMM). J-statistic has coefficient of 2.903738 with probability value of 0.574062 , which shows the model is significant and suitable to adduce the Contemporaneous Relationship between ROA, MPR, CRR, LDR and SDR. Table 7 shows that in this study only CRR as monetary policy instrument significantly relate to ROA, though negative. The other variables of monetary policy engaged in this study insignificantly impact ROA.

\subsection{Unrestricted VAR Analysis}

\subsubsection{VAR Lag Length Selection}

As statistically established, the first step in estimating the VAR model is to determine the lag length for a parsimonious specification. To achieve this, the researchers engaged all the automatic lag selection criteria as shown below;

Table 8. VAR Lag Order Selection Criteria

\begin{tabular}{|c|c|c|c|c|c|c|}
\hline Lag & LogL & LR & FPE & AIC & SC & HQ \\
\hline 0 & -83.20777 & NA & 0.000609 & 6.785213 & 7.027155 & 6.854884 \\
\hline 1 & -3.462143 & $122.6856^{*}$ & $9.42 \mathrm{e}-06^{*}$ & $2.574011^{*}$ & $4.025661^{*}$ & $2.992034^{*}$ \\
\hline
\end{tabular}

\section{Authors' computation output using E-view 10}

The VAR lag order selection criteria on table 8 reveals that lag length of 1 is selected at $5 \%$ level based on sequential modified LR test statistic, Final prediction error (FPE), Akaike information criterion (AIC), and Hannan-Quinn information criterion (HQ), indicating that VAR (1) specification is the parsimonious model and the plausible description of the data used. The researchers confidently proceed to estimate a VAR (1) model for the dynamic relationship between the deposit money banks' performance and monetary policy variables.

\subsubsection{Residual Diagnostic Test}

In furtherance of the global utility examination of the specified model, it is exposed to four more diagnostic tests; VAR Residual Serial Correlation LM, VAR Residual Heteroscedasticity, Inverse roots of Autoregressive Characteristic Polynomial and Normality;

Table 9. VAR Residual Serial Correlation LM Tests

\begin{tabular}{|c|c|c|c|c|c|c|}
\hline Lag & LRE* stat & Df & Prob. & Rao F-stat & df & Prob. \\
\hline 1 & 29.28355 & 25 & 0.2522 & 1.217703 & $(25,16.4)$ & 0.3454 \\
\hline
\end{tabular}

\section{Authors' computation output using E-view 10}

In Table 9, VAR Residual Serial Correlation LM Tests P-value of 0.3454, which an indication of rejection of the null hypothesis, showing evidence no serial correlation. 
Table 10. VAR Residual Heteroscedasticity Test

\section{Authors' computation output using E-view 10}

\begin{tabular}{|c|c|c|}
\hline Chi-sq & Df & Prob. \\
\hline 324.8501 & 300 & 0.1551 \\
\hline
\end{tabular}

Table 10 shows that Chi-sq is 324.8501 with P-value of 0.1551 . This is sufficient evidence suggesting of homoscedasticity the model.

\subsubsection{Stability Check}

To examine the stability of the estimated VAR (1) model, the researchers plots the inverted roots in relation to unit circle. It is statistically known that the estimated VAR model is stable if all the inverted points are inside the unit circle as shown below;

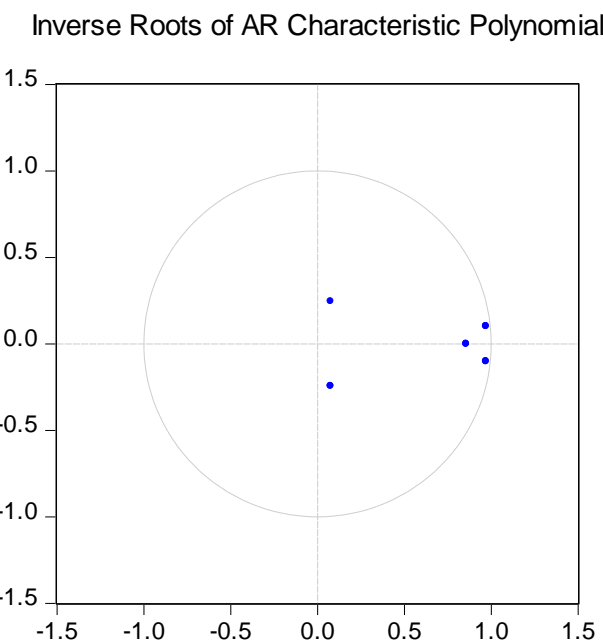

Figure 2. Graphical Representation of Inverse roots of AR Characteristic Polynomial

\section{Authors' computation output using E-view 10}

Figure 2 shows the inverse roots of the characteristics AR polynomial. It indicates that all roots fall or lie within the unit imaginery circle (modulus), an indication that VAR (1) model is stable.

Table 11. Normal Distribution Test

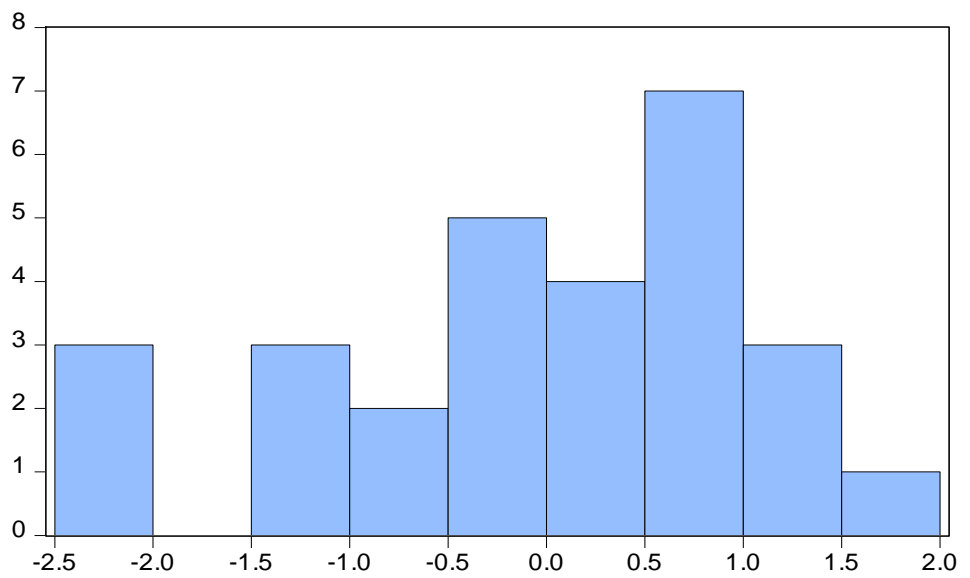

$\begin{array}{lr}\text { Series: Residuals } \\ \text { Sample 1990 2018 } \\ \text { Observations } 28 \\ \text { Mean } & -0.061295 \\ \text { Median } & 0.219660 \\ \text { Maximum } & 1.824537 \\ \text { Minimum } & -2.291459 \\ \text { Std. Dev. } & 1.093202 \\ \text { Skewness } & -0.596376 \\ \text { Kurtosis } & 2.652681 \\ & \\ \text { Jarque-Bera } & 1.800503 \\ \text { Probability } & 0.406467\end{array}$

Authors' computation output using E-view 10

From Table 11 above, it is seen that Jarque-Bera Statistic is 1.800503 with P- value of 0.406467 , confirming normal distribution.

4.8.4 Error Correction and Long Run Causality Test

Having established that the variables are cointegrated, there is likelihood of adjustment from short run to long run equilibrium. That is to say that errors encountered in the short run can be corrected or adjusted in the long run. To achieve the consistency, the researchers estimated the model with Vector Error Correction Estimates as shown below; 
Table 12. Vector Error Correction Estimates

\begin{tabular}{|c|c|c|c|c|c|}
\hline Error Correction: & D(LNROA) & D(LNMPR) & D(LNCRR) & D(LNLDR) & D(LNSDR) \\
\hline CointEq1 & -0.727709 & 0.033656 & 0.112234 & 0.025058 & 0.055891 \\
\hline & $(0.13951)$ & $(0.02471)$ & $(0.05212)$ & $(0.02212)$ & $(0.03016)$ \\
\hline & {$[-5.21614]$} & {$[1.36180]$} & {$[2.15347]$} & {$[1.13277]$} & {$[1.85309]$} \\
\hline
\end{tabular}

\section{Authors' computation output using E-view 10}

The analysis in table 12 above shows that error correction equation (CointEq1) has coefficient of -0.727709 and $\mathrm{t}$-statistic of -5.21614 . That means error correction parameter is negative and significant, satisfying the apriori expectation (condition), hence, significant. The speed of adjustment is $72.7 \%$. The cointegration already established is confirmed. That means short term errors can be corrected in the long run with annual speed of adjustment $72 \%$. It also confirms that long run causality flows from monetary policy instruments (MPR, CRR, LDR and SDR) to deposit money banks' performance (ROA)

\subsubsection{Short Run Causality Test}

To examine the short run causality implications of the variables, the researchers adopted VEC Granger Causality/Block Exogeneity Wald Test as depicted below;

Table 13. VEC Granger Causality/Block Exogeneity Wald Test

\begin{tabular}{|l|l|l|l|}
\hline \multicolumn{4}{|l|}{ Wald Tests } \\
\hline Dependent Variable: D(lnROA) & \\
\hline Excluded & Chi-sq & Df & Probability \\
\hline D(lnMPR) & 10.80231 & 1 & 0.0010 \\
& & 1 & \\
\hline D(lnCRR) & 1.951949 & 1 & 0.1624 \\
\hline D(lnLDR) & 1.317648 & 1 & 0.2510 \\
\hline D(lnSDR) & 0.177491 & 1 & 0.6735 \\
\hline All & 13.17271 & 4 & 0.0105 \\
\hline
\end{tabular}

\section{Authors' computation output using E-view 10}

Table 12 reveals that Chi-square statistic of 10.80231 with p-value of which is significant at 5\%, suggesting MPR cause ROA in both in the short run and long run. While, CRR, LDR and SDR have p-values of 0.1624, 0.2510 and 0.6735 respectively, indicating that they are not significant, indicating CRR, LDR and SDR do not cause ROA in the short run but in the long run. All monetary policy instruments (MPR, CRR, LDR and SDR) jointly cause bank performance (ROA) as shown in above with p-value of 0.0105 , but not separately as seen already.

\subsubsection{Impulse Response of ROA to Its Own Shock and Shocks from MPR, CRR, LDR and SDR}

As seen from the previous analysis, all the monetary policy variables (MPR, CRR, LDR and SDR) contemporaneously and inter-temporally do not jointly cause or relate banks' performance (ROA), hence need to examine the shocks or innovations of ROA from itself and from MPR, CRR, LDR and SDR. Again, examine the dynamic impacts or shocks of monetary policy variations on banks' performance. This is achieved with impulse responses and variance decomposition as depicted below 
Response to Cholesky One S.D. (d.f. adjusted) Innovations \pm 2 S.E.

Response of LNROA to LNROA

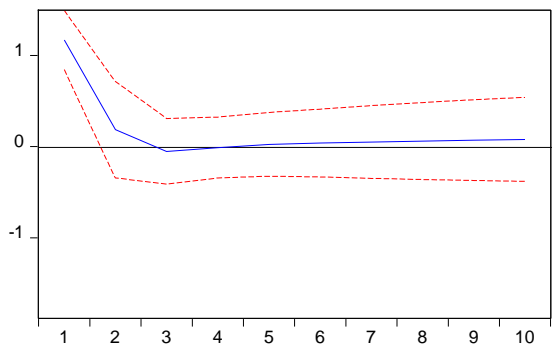

Response of LNROA to LNCRR

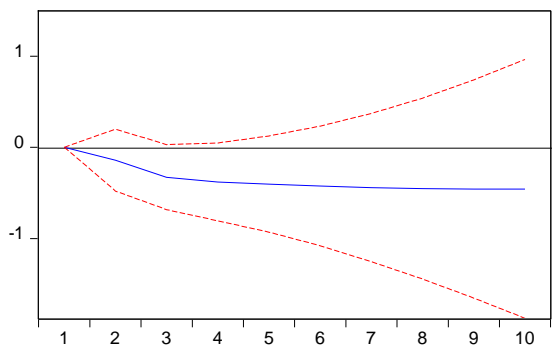

Response of LNROA to LNSDR

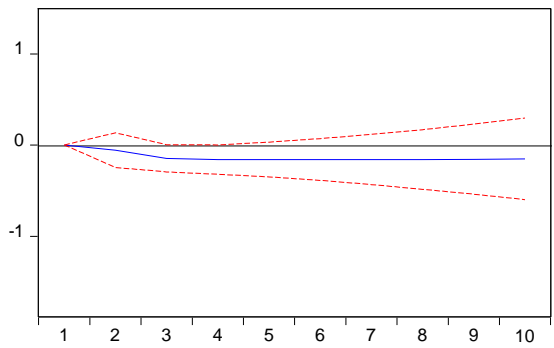

Response of LNROA to LNMPR

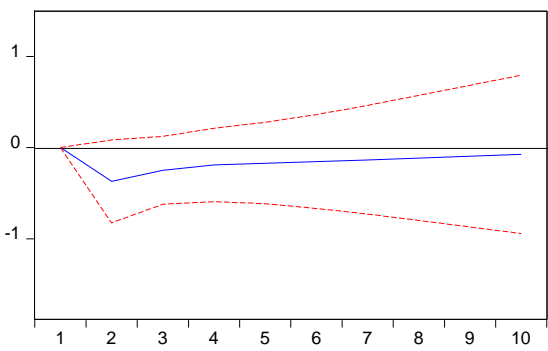

Response of LNROA to LNLDR

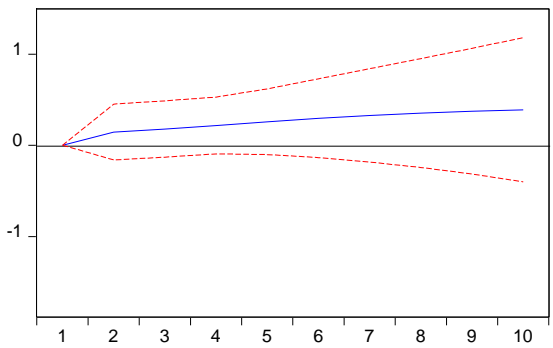

Figure 3. Graph depicting Responses of ROA to Shocks

\section{Authors' computation output using E-view 10}

From figure 3, the impulse response function shows one time shock to the variables. It shows that ROA responds positively to own shock from first year to third year and fades away slightly to negative then returned to the threshold until the tenth year. ROA responds negatively from the shocks of MPR, CRR and from first to tenth year, but ROA responds positively to shocks from LDR from the first to tenth year.

\subsubsection{ROA Own Shocks and Shocks from MPR, CRR, LDR and SDR}

-Variance Decomposition

Table 14. Variance Decomposition Results

\begin{tabular}{|c|c|c|c|c|c|c|}
\hline Period & S.E. & LNROA & LNMPR & LNCRR & LNLDR & LNSDR \\
\hline 1 & 0.974371 & 100.0000 & 0.000000 & 0.000000 & 0.000000 & 0.000000 \\
\hline 2 & 1.304806 & 59.77006 & 13.01101 & 3.698045 & 23.51961 & 0.001280 \\
\hline 3 & 1.592551 & 40.16782 & 31.47010 & 6.365645 & 21.56865 & 0.427782 \\
\hline 4 & 2.387839 & 36.28799 & 30.86858 & 3.084018 & 29.56912 & 0.190289 \\
\hline 5 & 2.808975 & 29.33999 & 37.57812 & 5.174465 & 27.66135 & 0.246070 \\
\hline 6 & 3.629477 & 32.22059 & 35.26160 & 3.662281 & 28.70728 & 0.148250 \\
\hline 7 & 4.122452 & 29.52260 & 37.96046 & 4.997961 & 27.35511 & 0.163869 \\
\hline 8 & 4.885131 & 31.95756 & 36.15144 & 4.174879 & 27.59845 & 0.117672 \\
\hline 9 & 5.379375 & 30.63197 & 37.57443 & 4.985324 & 26.68369 & 0.124585 \\
\hline 10 & 6.076129 & 32.33946 & 36.31089 & 4.477894 & 26.77304 & 0.098719 \\
\hline
\end{tabular}




\section{Authors' computation output using E-view 10}

From Table 14, own shock caused 100 percent variations in the first period and diminished greatly to $32 \%$. That suggests that own shock exerted huge influence in the cause of variation on bank performance followed by MPR that started from $0 \%$ in the first year and rose greatly to $37 \%$ in the fifth year, then to $36 \%$ in the tenth year. In the same magnitude is LDR. The variations from CRR and SDR are mild.

\section{Conclusions and Recommendations}

In this study greater efforts were dissipated to unravel the relationship and causal effects of monetary policy variables and performance of deposit money banks in Nigeria. A good number of tools were engaged to estimate the models specified, starting from those suitable for examination of global utility to VAR methodology. The following major findings are that cash reserve ratio negatively and significantly affects the performance of deposit money banks in Nigeria. This shows that deposit money banks in Nigeria are starved with fund due to high reserve ratio as always stipulates by the Central Bank of Nigeria. No wonder Onoh (2007) opined that Minimum reserve ratio is difficulty in predicting the right minimum reserves. It is considered not only risky but dangerous to toy with the instrument in the attempt to influence the reserve component of the monetary base equation; the monetary base itself being an unstable indicator variable under constant onslaught from exogenous variables. This hampers the credit creation of deposit money banks in Nigeria, thereby negatively affecting their performance as found. This corroborates the apriori expectation and study by Ndugbu and Okere (2015) and frustrates the Anticipated Income Theory. The study also found other monetary policy variables insignificant to the performance of deposit money banks in Nigeria corroborating the findings of Dare and Okeya (2017). It was also found that own shock from bank performance exerts greater fluctuations in the banking business in Nigeria. It was also found that apart from banks own shock; banks respond negatively to shocks from major monetary policy instruments. It was observed that Monetary Policy Rate cause bank performance ROA in both in the short run and long run. While, Cash Reserve Ratio, Liquidity Ratio and Saving Deposit Rate do not cause ROA in the short run but in the long run. No wonder Cash Reserve Ratio has negative and significant impact on bank performance. It was also found that monetary policy instruments jointly cause bank performance in the short and long run as opposed by individual instruments in Nigeria.

The researchers therefore suggest that central bank of Nigeria reduce the cash reserve ratio to enable deposit money banks extend loans to their potential customers, thereby enhance performance. Since banks own shock constitutes greater fluctuations in the banking industry, it is advised that bank outside the monetary policy measures should do adequate credit analysis before extension of credit to customers.

\section{Suggestion for Further Study}

The researchers suggest further study on the subject matter to be extended to other financial institution and across the frontier of Nigeria. This will help to validate possible inferences, theories and policy making.

\section{References}

Ajayi, F. O., \& Atanda, A. A. (2012). Monetary policy and bank performance in Nigeria. A two-step cointegration approach. African Journal of Scientific Research, 9(1), 463-476.

Akanbi, T. A., \& Ajagbe, F. A. (2012). Analysis of monetary policy on commercial banks in Nigeria. African Journal of Business Management, 6(5), 12038-12042. https://doi.org/10.5897/AJBM11.1843

Akomolofe, K. T., Danladi, J. D., Babalola, O., \& Abah, A. G. (2015). Monetary policy and commercial banks' performance in Nigeria. Public Policy and Administrative Research, 5(9), 158-166.

Central Bank of Nigeria. (2009). Monetary policy framework in Nigeria.Research Department of Central Bank of Nigeria, Abuja.

Dare, F. D., \& Okeya, I. O. (2017). Monetary policy and commercial banks' credit performance: Evidence from UBA Plc. IOSR Journal of Economics and Finance (IOSR-JEF), 8(4), 60-67.

Ejem, C. A., Ogbulu, O. M., Ogbonna, U. G., Oriko, B. O., \& Jombo, C. O. (2020). Foundation of banking and insurance in Nigeria: An eclectic approach (2nded.). Aba: Logicgate Media Ltd.

Ekezie, E. S. (2002). The elements of banking: Money, financial institutions and markets.Onitsha:Africana-FEP Publishers Limited.

Ekpung, G. E., Udude, C. C., \& Uwalaka, H. I. (2015). The impact of monetary policy on the banking sector in Nigeria. International Journal of Economics, Commercial and Management, 3(5), 1015-1031.

Lindgren, C., Garcia, G., \&Saal, M. I. (1996). Bank soundness and macroeconomic policy. Washington: International Monetary Fund, Publication Services. 
Ndugbu, M. O., \& Okere, P. A. (2015). Monetary policy and the performance of deposit money banks: The Nigerian experience. European Journal of Business and Management, 7(17), 65-72.

Nguyen, T. N., Vu, N. H., \& Le, H. T. (2017). Impacts of monetary policy on commercial bank's profit: The case of Vietnam. Asian Social Science, 13(8), 32-40. https://doi.org/10.5539/ass.v13n8p32

Nwankwo, G. O. (1991). Bank management: Principles and practice. Ibadan: MalHouse Press Limited.

Nzotta. S. M. (2004). Money, banking and finance (2nd edition): Theory and practice. Owerri: Hudson-Jude Publishers.

Okoye, V., \& Eze, R. O. (2013). Effect of bank lending rate on the performance of Nigeria deposit money banks. International Journal of Business andManagement Review, 1(1), 34-43.

Onoh, J. K. (2007). Dimension of Nigeria's monetary and fiscal policies-Domestic and external. Lagos: Astra Meridian Publishers.

Onuorah, C. A., Shaib, I. O., Oyathelemi, E., \& Friday, O. I. (2011). The impact of monetary policy on micro economy and private investment in Nigeria. Research Journal of Finance and Accounting, 2(6), 65-75.

Osiegbu, P. I. (2006). The level of commercial banks' compliance with CBN monetary policy credit guidelines. Journal of Social Science, 13(1), 11-14. https://doi.org/10.1080/09718923.2006.11892525

Rose, P. S., \& Hudgins, S. C. (2010). Bank management and financial services (8thed.). New York: McGraw Hill.

Udeh, S. N. (2015). Impact of monetary policy instruments on profitability of commercial banks in Nigeria: Zenith bank experience. Research Journal of Finance and Accounting, 6(16),6-10.

Udude, C. C. (2014). Monetary policy and economic growth in Nigeria. Journal of Policy and Development Studies, 9(1), 234-247. https://doi.org/10.12816/0011194

\section{Copyrights}

Copyright for this article is retained by the author(s), with first publication rights granted to the journal.

This is an open-access article distributed under the terms and conditions of the Creative Commons Attribution licensewhich permits unrestricted use, distribution, and reproduction in any medium, provided the original work is properly cited. 